\title{
Why India Will Fail to Attract Global Faculty
}

\section{Philip G. Altbach and Eldho Mathews}

Philip G. Altbach is research professor and founding director of the Center for International Higher Education, Boston College, US. E-mail: altbach@bc.edu. Eldho Mathews is an independent higher education researcher based in New Delhi, India. E-mail: eldhomathews@gmail. com.

T twas reported recently that there are just 40 foreign teach1 ers at all of the Indian Institutes of Technology (IITs) - I percent of the total faculty of 5,400-despite the government's goal to attract 20 percent international faculty to the IITs. Internationalization in general, and the appointment of global staff in particular, is central to the new "Institutions of Eminence" program. The goal is even more lofty after the IIT Council last year recommended the recruitment of foreign faculty on a tenure basis. The Graded Autonomy Regulations of the University Grants Commission (UGC) now also allow the highest performing universities to hire up to 20 percent foreign faculty over and above the total sanctioned faculty strength on tenure basis.

It is virtually impossible for India to attract large numbers of international professors of high standing and ability without dramatic changes in many aspects of Indian higher education. This involves not only liberal funding with regard to salary and allowances, but also reforms in the existing governance structure in universities and changes in government regulations. For decades, the flow of academics has been in the opposite direction-from India to other countries. One can find top Indian talent, for example, at many American universities, employed as professors in many fields or in senior administrative positions such as university presidents or deans of schools-for example, the dean of the Harvard Business School and the dean of Harvard College.

\section{TyPes OF PROFEsSORS}

There are two kinds of international academics to be considered. The first category is accomplished senior professorsthese would be very difficult to lure to India. Established in their careers abroad, with attractive international salaries and often with family and other obligations, they are embedded both in their universities and locales. Some might be willing to have some kind of joint appointment in India if the conditions were favorable and their research interests were relevant to India. Recently retired academics might be attracted to an "Indian adventure," but these scholars may no longer be productive researchers. The most realis- tic possibility is academics of Indian origin ("non-resident Indians" or NRIs) who have successful careers abroad and might be attracted back. The main recent initiative of the Indian government in that respect, the Global Initiative of Academic Networks (GIAN), has been successful in attracting many academics of Indian origin from different countries for shorter periods of time. However, the experiences of two prominent universities sponsored by Indian and other national governments-South Asian University in Delhi, sponsored by the member states of the South Asian Association for Regional Cooperation (SAARC), and Nalanda University in Bihar, sponsored by the country participants of the East Asia Summit-show that offering higher salaries (almost double those on offer to Indian academics, plus exemption from taxation) has not been a very successful strategy for attracting faculty of foreign origin, especially senior academics.

\section{It is virtually impossible for India to at- tract large numbers of international professors of high standing and ability without dramatic changes in many as- pects of Indian higher education.}

The other group are younger scholars who may have fewer ties to their universities and local communities and are thus more mobile. Depending on their disciplines, some may have difficulty in locating a permanent academic job at home due to a tight academic job market. These academics are, of course, a greater risk since they may not be destined for distinguished careers. They may not add to the immediate prestige of the Indian universities that hire them since they do not have established reputations. However, they can provide quality teaching and research, and they often bring a useful international perspective. However, the experience of other countries that have hired young academics on the international market, for example Russia, is that many leave once they have built up research publications.

\section{The Challenges}

In some ways, the best Indian universities would require a kind of "cultural revolution" to join the ranks of global world-class universities - and to be able to lure top faculty. The structural and practical realities of Indian universities make them generally unattractive for academic talent from abroad. A few examples indicate some of the challenges. 
- Indian academic salaries are not globally competitive, even taking into account variations in living costs. Senior academics at US research universities typically earn $\$ 130,000$ and up annually, and those at top US universities can earn $\$ 200,000$ or more. The average salaries for full-time academics is $\$ 73,000$, with those in high demand fields in the sciences, business, and others earning significantly more. In comparison, Indian salaries in the IITs, according to the latest Pay Commission recommendations, starts at $\$ 17,622$ for assistant professors, rising to around $\$ 38, \mathrm{I} 65$ for full professors. Higher ranks earn somewhat more. China, which is also actively luring top international faculty to its research universities, offers salaries of \$100,000 or more, along with additional research funding.

- Indian public institutions have little experience in hiring international faculty and much experience with stifling bureaucracy. This means that processing academic appointments for foreign faculty is quite time-consuming, as approval by multiple government departments is needed in addition to standard university procedures. Indian public universities do not have processes in place to handle such appointments.

- International faculty cannot be offered long-term appointments in Indian public institutions. Fiveyear contracts are all that is available-although these may be extended. Thus, there is little job security.

- Obtaining research funding is difficult and the resources available, by international standards, are quite limited. The bureaucratic procedures relating to research grants are also daunting. This is in sharp contrast to China, where significant research funding is offered almost automatically to foreign faculty.

- Few IITs have considered foreign hiring as an important part of their academic initiatives. Premier institutions such as IIT Bombay now provides foreign faculty around \$I,500 as relocation allowance. Although a seed grant of up to $\$ 29,000$ is provided to new international faculty members to meet the initial cost for setting up a research laboratory, only around $\$ 2,900$ is provided as a Cumulative Professional Development Allowance (CPDA) every three years for presenting papers at conferences. In addition, political and security clearance from the ministries of external affairs and home affairs are necessary in every case for individuals with foreign passports.

\section{Different Strategies}

On the other hand, a few "elite" nonprofit private universities such as O.P. Jindal, Azim Premji, Ashoka, Shiv Nadar, Ahmedabad, Krea, and the Indian School of Business have adopted different strategies, attracting foreign nationals and Indians who have studied at prestigious foreign universities by offering higher salaries and other benefits that are not available to local hires. The faculty diversity of O.P. Jindal Global University, which is located in the national capital region of Delhi, stands out with 7I full-time foreign faculty originating from 32 countries. The key motivation for hiring foreign faculty at all these institutions, mainly in liberal arts and professional courses such as engineering, management, and law, is to improve international competitiveness and secure positions in global rankings, which in turn should also attract more motivated students.

The measures taken by these new private universities with, by Indian standards, considerable resources have proved that it is possible to attract foreign faculty, at least those with an Indian ethnic background. But the challenges faced by public institutions, even those as high quality as the IITs and the best universities, seem insurmountable, at least in the context of the current Indian higher education environment and bureaucratic and legal framework.

\section{Indian Research Universities and Global Rankings}

\section{Pankaj Jalote}

Pankaj Jalote is distinguished professor and founding director, IIIT-Delhi, India.E-mail: jalote@iiitd.ac.in.

A more detailed report is available on the website of Current Science, May 2019 issue.

$\mathrm{T}$ his century has seen a dramatic rise in the importance of global university rankings. In India, as in many other countries, there is a strong desire to have some of the nationally preeminent universities recognized among the best in the world. Currently, there are no Indian universities in the top 200 of the Academic Rankings of World Universities (ARWU, or "Shanghai ranking"), the Times Higher Edu- 